\title{
A EFICÁCIA DO DISPOSITIVO DE REPOSICIONAMENTO A CURTO E A LONGO PRAZO
}

Régis Borges MACHADO; Marcelo WEBER

Dentre as alterações internas da ATM, os desarranjos do complexo côndilo-disco estão entre as mais prevalentes. Quando sintomáticos, os deslocamentos de disco com e sem redução devem ser controlados inicialmente por medidas pouco invasivas. O dispositivo de reposicionamento anterior é um tipo de aparelho interoclusal utilizado no manejo dessas disfunções. Este trabalho tem por objetivo discutir a eficácia deste dispositivo no tratamento das alterações internas da ATM, através de uma revisão da literatura. 